\title{
TECHNOLOGY, SOCIETY, AND VISIONING THE FUTURE OF MUSIC FESTIVALS
}

\author{
MARTIN ROBERTSON, *† IAN YEOMAN, $\ddagger$ KAREN A. SMITH,§ \\ AND UNA MCMAHON-BEATTIEף \\ *Event Management, Faculty of Management, Bournemouth University, Poole, Dorset, UK \\ †Honorary Fellow, College of Business, Victoria University, Melbourne, Australia \\ $\ddagger$ Tourism Futures, Victoria Management School, Victoria University of Wellington, \\ Wellington, New Zealand \\ $\S$ Tourism Management, Victoria Management School, Victoria University of Wellington, \\ Wellington, New Zealand \\ qDepartment of Hospitality and Tourism Management, University of Ulster, Belfast, UK
}

\begin{abstract}
Many music festivals fail because the experiences offered do not ensure relevance and meaning to the attendee. Engagement with new and virtual landscapes and with the enhanced sensory feelings and imaginations that technologies can offer may alleviate this. Utilizing a futures frame, this conceptual article contributes to the pursuit of successful future event design by applying a normative visionary methodology - employing trend analysis, scenarios, and science fiction to create prototypes that may assist in the formation of appropriate experience options and opportunities for music festivals of the future. It is proposed that this technique may aid positive social outcomes.
\end{abstract}

Key words: Music festivals; Future studies; Scenarios; Play; Science fiction; Society

\section{Introduction}

As both an attraction for visitors (Bernick \& Boo, 2013; Lee, Charles, \& Lee, 2012; Mayfield \& Crompton, 1995; Roselyne, 2011) and as an aspect of everyday social life, the festival is a manifestation of the experience economy (Evans, 2009; Pegg \& Patterson, 2010). Festivals stimulate attendees' emotions, memories, fantasies, and the formation of multiple images (Ferdinand \& Williams, 2013;
Holbrook \& Hirschman, 1982). They also include activities that are often formed by or gain funding to meet a variety of political and public policy functions (Dredge \& Whitford, 2010; Whitford, 2009). They are intrinsically linked to society and its well-being (Ballantyne, Ballantyne, \& Packer, 2014; Packer \& Ballantyne, 2011).

In thinking about society we need to look to the future. As a multidisciplinary approach, futures studies is not only an exploratory activity, it is a 
base for ensuring appropriate strategy now and into the future. Put simply, futures studies can be used to ask big questions and to form responses to these questions. The speed of technological, economic, and social change and the way in which our lives interact with these changes requires deeper questioning. As Godet and Roubelat (1996) imply, "the faster you drive, the further your headlights must shine” (p. 165). A futures methodology therefore can heighten capacity for an individual or organization to anticipate change (Glenn, 2009). For the music festival to survive it is vital to assess current and future environments, that is, to deal not only with current issues such as restraints on funding, a decreasing number of volunteers (Lockstone \& Smith, 2009), the desire by attendees for a novel experience, the impact of online access to music (Gibson \& Connell, 2005; McCarthy, 2013), and the pressures of climate change on outside events (Mair, 2014), but also to consider the lesser known or unknown factors that may eventuate.

Music festivals are the focus of this conceptual article, which asks how technology stimulates change in experience needs and how, through scenario planning or forms of future visioning (Birtchnell \& Urry, 2013; van der Helm, 2009), festival management may be able to precipitate or drive experience needs. That is, a process by which technological advancements (science fact) allows observation of the way in which nonwork (play) activity is changing, trend analysis (consumer fact) allows observation of the way in which the future can be said to be manifest now, and science fiction (fictional representation) allows for a paradigmatic explanation of how such things could occur. These processes may then be used to form prototypes (approximations) for the future (Bell, Fletcher, Greenhill, Griffiths, \& McLean, 2013; Graham, Callaghan, \& Greenhill, 2013).

Accordingly, this conceptual work contributes to the pursuit of successful future event design by applying a normative visionary methodologyutilizing science fiction to create prototypes that may assist in the formation of appropriate experience options and opportunities for music festivals of the future. It is proposed that this technique may aid positive social outcomes.

\section{Literature Review}

Staged events such as music festivals may be popular because of their clear fit into the experience economy, which in itself can be considered as a megatrend in today's society (Bille, 2012; Mehmetoglu \& Engen, 2011) - they are social manifestations. A driving force behind this megatrend in developed and developing countries is the need of individuals to create their own identities (Arcodia \& Whitford, 2006; Hauptfleisch, 2006) and to shape their personalities in lives characterized by increasing freedom and an improving economy (Yeoman, 2013). As such, experiences function as a personal source of information for the stories people tell about their lives (Mehmetoglu \& Engen, 2011).

At the same time, technological advancements have altered the way in which consumers spend their leisure time; influencing the value of personal stories, social functioning, and even affecting experiences themselves. Current forms of technology and future emerging technologies associated with thought identification, "neuroimagining" and dream capture, are dramatically changing forms of experience. These technological advancements, as well as social and experiential shifts, have ensured that music festival participation is an increasingly significant societal activity, now and into the future (Ballantyne et al., 2014; Brooks, Magnin, \& O’Halloran, 2009).

\section{Music Festivals, Technology, and Experience}

Music festivals in their more contemporary format may be viewed as emerging from the postSecond World War period (Gibson \& Connell, 2012) and what Frey (1994) describes as a deficit of live artistic performance in society. Currently, most cities or regions are likely to host at least one music festival regularly. The rapid growth in the number and geographical spread of these event types since the 1990s has been spectacular (Frey, 1994; Gibson, 2007).

Music festivals are unique special events (Bowen \& Daniels, 2005; Gelder \& Robinson, 2009) that attract audiences for a variety of reasons. Further, the atmosphere of music festivals offers socialization 
and other non-music-oriented experiences vital to their success (Bowen \& Daniels, 2005; Nordvall, Pettersson, Svensson, \& Brown, 2014).

As an example, the Glastonbury Festival (founded in 1970) is described as the largest greenfield festival of music and performance in the world (Glastonbury, 2011). In their media-centered analysis of Glastonbury in 2010, Flinn and Frew (2014) describe the event as commanding a focal position within the culture of music festivals. As with other researchers (Gelder \& Robinson, 2009), they report that with an ageing demographic profile, it also has appeal to new markets and offer new opportunities for socialization, necessitating some change.

In their analytical snapshot of the present, Flinn and Frew (2014) view recent changes to the Glastonbury Festival as examples of modern festivity, and as systematic of a commodification of experience, which they see as happening in many music festivals. In addition to changes to the physical environment of these festivals, they highlight the significance of attempts by management to manage the macro and social media. They conclude that this attempt has the potential to remove (for the festival attendee) the unique individualistic experience of "rough comfort” (p. 429). Their study utilizes a media framing methodology (Falkheimer, 2007; Robertson \& Rogers, 2009; Scheufele \& Tewksbury, 2007) focusing on social media to assess the way in which festivals (and social interactions within them) are framed. In viewing the current business involvement in social media as a conspiratorial attempt by corporations to manipulate consumption, their study predicts a future in which cocreation (Rihova, Buhalis, Moital, \& Gouthro, 2014; Sanders \& Stappers, 2008) and the power of social media are transformative and the power of technology becomes vital.

Robertson and Brown (2014) apply a more operational design view of the future of festivals; agreeing that technology and social media are transforming both the experience and the control of the festival, while proposing that convergence of operations and community will not make the professionalism of design, leadership, and safety any less important than at present. Rather, they imply that the aggregation of information and discussion relating to festivals will harmonize community cocreation and professionalism. Recent music festivals, such as the electronic dance music festival TomorrowWorld (www.tomorrowworld.com), already take on board integration of the event experience within the event's operation.

In 2014, TomorrowWorld received approximately 160,000 guests. This 10 -year-old event seeks to integrate experience with IT operations and thus enhance the presence of the festival attendee (Luxford \& Dickinson, 2015). As well as access to streaming performances in any number of locations, 3D technology allows virtual integration to the extent that individual artists can offer their own virtual experience within the festival, for example, offer the opportunity to "hangout backstage with a DJ before going on stage with them" (http://www. huffingtonpost.com/jeremy-wilson/the-future-ofmusic-festi_b_6806904.html).

Interestingly, in 2015 it was the management of the "real" TomorrowWorld experience (as affected by 3 days of rain) that severely diminished the overall experience. With inaccessible car parks, severe traffic congestion, and reportedly thousands of stranded festival goers (http://www.atlantamag azine.com/news-culture-articles/scenes-from-to morrowworld-2015-music-and-mud/) and severe restrictions placed on entrance to the festival on the final day, organizers were forced to apologize and give refunds (www.tomorrowland.com/news). Social media became both messenger and agitator through this time.

Although social media in the context of music festivals has received relatively little research coverage (Hudson \& Hudson, 2013; N. L. Williams, Inversini, Buhalis, \& Ferdinand, 2015), the current variants of social media available to the industry and utilized by event attendees, such as social publishing (e.g., blogs, YouTube, Flickr, Slideshare, Twitter), social collaboration (e.g., instant messaging, crowdsourcing), social networking (e.g., Facebook, FriendFeed, and Linkedin), social feedback (e.g., Yelp and TripAdvisor), and blogging/ microblogging (e.g., Twitter, Blogger, and Tumblr) are extensive and, for many festival attendees and festival operators, very common and significant streams of information and interaction. Similarly, the development of onsite festival technologyfrom streaming technology and integration into 
handheld or touchable technology (e.g., a multilayering of mobile video and interactive mapping installations) - is well established. These have an increasing significance to festival attendees and those working in and managing events.

This article does not offer a judgment or a record of the forms of social media and other technology because their development is so dynamic. Instead, it concerns itself with the possible function of social communication and technological platforms in adding value to the festival experience of the future-and contributing to positive social outputs. As such, it also utilizes (but is not driven by) a body of knowledge that documents the prospect for social inclusion and other positive social and cultural benefits from music festivals (Andersson, Armbrecht, \& Lundberg, 2012; Laing \& Mair, 2015).

\section{Cocreation and Value of Experience}

The importance of added value derived by users from their experience is well recognized in the tourism literature (Smith, 1994; Stamboulis \& Skayannis, 2003; Van Rekom, 1995). From a mixed methodological analysis of the impact of music festivals on the psychological and social well-being of young people attending, Packer and Ballantyne (2011) conclude that there are four clear facets of experience. These are music experience; festival experience; social experience; and separation experience. Each of these contributes to the overall experience value of a music festival. Southern et al. (2014) highlight the significance of the social experience; expounding three types of social interaction that need focus to best ensure positive festival experiences. These are known-group socialization, external socialization (i.e., the way in which new meetings are formed), and audience socialization (i.e., the positive social experience in the enclosure of an event or festival).

The benefits to understanding the possible experiences of music festival goers of the future are threefold. First, in understanding experience, organizers have a greater opportunity to ensure the best and most positive experience for the festival visitor while mitigating the negatives, and "enhance psychological and social wellbeing” (Packer \& Ballantyne, 2011, p. 179). The music experience in itself can have a profound link with human emotion (Packer \& Ballantyne, 2011; Zbikowski, 2010). Moreover, the musical form offers not only an avenue for self-expression, it can also bring with it knowledge and what Langer (1953) describes as "a tonal analogue of emotive life" (p. 27). Thus, music experiences can be transformative and can remove the recipient from the sense of the everyday (Boyce-Tillman, 2009) by bringing a sense of the other (i.e., a state of liminality) (Boyce-Tillman, 2009; Howard-Grenville, Golden-Biddle, Irwin, \& Mao, 2011). The transformative and liminal capacity of the music festival experience is likely to be seen as a central component of the business model that organizers of these events are likely to adhere to, now and in the future.

In a contemporary business management model, experience is already a core component of the business management process (Hallberg \& Harsløf, 2013; Newbery \& Farnham, 2013). It is not only a response to an environment in which traditional institutions and their hierarchies are becoming less trusted (Boswijk, 2013; Grabner-Krauter, 2010), for the provider it is also a way of ensuring added value for the experience. Understanding experience will allow greater efficiencies for the business providing the experience, including greater ease in communication between the consumer (the attendee), human resources (staff), and revenue streams (Hallberg \& Harsløf, 2013). Experience is thus a core part of the business management platform in which the values of the individual and the business must coexist and relate to their respective values (Brand \& Rocchi, 2011; Verhoef et al., 2009). It is in recognition of this coexistence that the significance of collective creativity (cocreation) and its capacity to provide more value to the experience (Sanders \& Stappers, 2008; van Limburg, 2008), and the dynamic nature of interrelations within, has necessitated further research (Rihova et al., 2014).

Although it is not the purpose of this article to discuss the interrelations of cocreativity, it is prudent to indicate that relationships can be demonstrated between performance and audience (Brown \& Hutton, 2013; Hagen, 1991; Ryan, 2012); audience and organization (Ramaswamy \& Gouillart, 2010; Ryan, 2012); audience and audience (customer to customer) (Rihova et al., 2014); and communities with performance (Hollands, 2010; 
Robertson \& Yeoman, 2014). All these interrelationships have implications for the four facets of experience previously stated. It is also important to recognize that cocreation has the potential to affect the perceived quality of production, as well as its market value, in a negative and positive frame (Robertson \& Brown, 2014). Indeed cocreation has potential for producing collaborations that may also be contested and negative (Flinn \& Frew, 2014; Walmsley, 2013). From either viewpoint there is recognition that cocreation outcomes have far-ranging social implications.

\section{Value}

From the literature reviewed, there is agreement that increasing the value of experience for the festival attendee (as individual and collaborator) has an association with the intellectual or emotional depth of participation or involvement. Accordingly, music festival attendees could benefit from a greater understanding of the components that promote their own transformative experience in order to manipulate, personalize, or completely design the experience (Boyce-Tillman, 2009, 2013).

In seeking depth of participation and ensuring platforms for festival attendees to pursue transformative experience, individually or collaboratively, it is vital that this is seen not as a continuum but as multiple possibilities for the future. Furthermore, transformative experience also needs to be framed so as to ensure authentic futures (i.e., futures that engage their actors). One way to work towards this is through the use of scenario building. Scenario building is used by creative and arts organizations to inform strategic action (Rhisiart, 2013; Selwood, 2007). Scenario planning has been applied to event management research by Moital, Jackson, and Couillard (2013), Yeoman (2013), and Yeoman, Robertson, and Smith (2012). This conceptual article contributes to this body of work to form appropriate experience options and opportunities (scenarios) for music festivals of the future.

\section{Methodological Approach}

As a conceptual base, the authors propose a number of visionary futures that demonstrate how music festivals may be experienced. The way in which technology is changing consumption is considered, as is music festival form and the society of which it is a part. The fictional prototyping process introduced by Johnson (2011) and applied by Graham et al. (2013) to the traditional product development process informs this study. In essence, this process asks: what is the technology, how can the technology be used, who is the customer, what is the experience that is required, and how will their experience be enabled? It refers to technological advancements (science fact), trend analysis (consumer fact), and science fiction (fiction) to form prototypes (approximations) of what the future experience at music festivals may be like (see Fig. 1). The following sections discuss the value of these four elements and how they interact, and how they are used and mediated to ensure understanding and utility.

\section{Prototyping}

For all areas of business, the acceleration of technological development has had a clear influence on design. The same is true for festivals (Ballantyne et al., 2014; Brown \& James, 2004; Nelson, 2009; Yeoman, 2013; Yeoman, Robertson, \& Wheatley, 2015).

Prototypes have the capacity to give a reflective analysis of business visions (i.e., bring sensory substance to a concept). They are used in all types of business, and are underwritten by a general vision relating to the strategic direction in which the business wishes to progress. Prototyping and visions have been criticized for giving only limited consideration of their social impact (Southern et al., 2014) or indeed their design quality (Brown \& James, 2004). More recent discussion of prototyping in the discipline of service design identifies the need to manage interaction and related interface issues, for example, between people and technology, and affective design, that is, "bringing emotion and play into a rational design and engineering mindset" (Saco \& Goncalves, 2008, p. 11). It is defined by its holistic nature (i.e., the social context, its stakeholders, and the customer experience). In this interdisciplinary perspective it is possible to divide the activity into six areas. These are: understanding (assessing); thinking (framing); generating (exploring); 


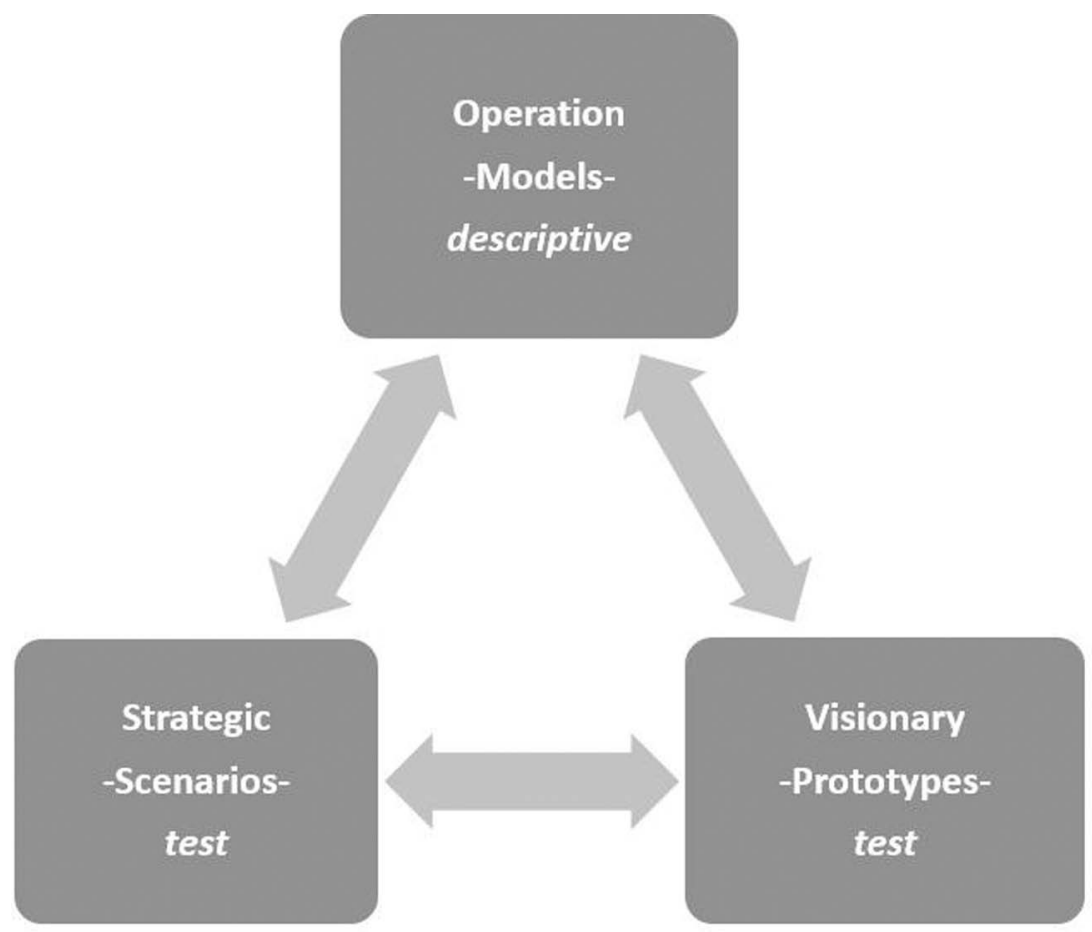

Figure 1. Relationship between forms of management, models, scenarios, and prototypes (after Bell et al., 2013).

filtering (reducing); explaining (rationalizing); and realizing (building) (Saco \& Goncalves, 2008). It is a collaborative and cocreative activity (Blomkvist \& Holmlid, 2010; Simo, Satu, Essi, \& Antti, 2012) and is well suited to the design of events and festivals (Miettinen, Valtonen, \& Markuksela, 2015).

In the world of software applications (apps), and social media development, one form of prototyping activity is in the Hackathon. Hackathons (derived from hack and marathon) stem from computer programming meetings where programmers collaborate intensely over a short period of time in response to a technical problem or query (Briscoe \& Mulligan, 2014). This type of activity has begun to gain ground within the professional and academic fields of arts and culture, and includes the creation of innovative digital prototypes for the creative industries (Briscoe \& Mulligan, 2014). For festivals, the growth of community partnership laboratories and crowdsourcing media applications has similarly facilitated much cocreative prototyping activity (see for example, Shimray \& Ramaiah, 2015). Another process that is being considered increasingly in building and prototyping visionsand applied here to this work-is science fiction prototyping.

\section{Science Fiction}

Science fiction has been utilized as an inspiration for design prototypes for a long time and is at the root of many innovative designs (Bell et al., 2013; Birtchnell \& Urry, 2013). By systematically altering technological, social, or biological conditions, science fiction attempts to explain the possible consequences of design (Parker, Fournier, \& Reedy, 2007). Importantly, as the writings are rational portrayals of possible futures (Putnam, 1981), science fiction actually informs future studies. Indeed, they contextualize technologies within the social sphere and explore their implications (Kirby, 2010; Southern et al., 2014). Hence, when representing or explaining a science fiction approach, explanation is validated and purposeful, inspiring prototyping and also instructive to business management (Bell et al., 2013; Birtchnell \& Urry, 2013; Graham et al., 
2013). A creative fictional prototype draws on the imagery and imagination of science fact (Fig. 2). It enhances design ideas, that is, it is a design tool that can explore the consequences of change (Graham et al., 2013).

\section{Trend Analysis}

Trend analysis depends less on science fact and is used to facilitate insight into how the world is performing now, and to stimulate foresight (Yeoman, 2013). Trend analysis, from the Future Foundations omnibus survey of households (www.futurefoun dation.net), is used here because of the comprehensive account of consumer behavior it offers (based on surveys of 5,000 UK households, repeated six times a year, plus a similar number of respondents in other countries of the world). The use of trend analysis to form predictive futures must be viewed with caution as it is determined by an assumption of a constant condition (Bell et al., 2013). By adding other forms of qualitative data, and other methods of future analysis (i.e., triangulation), trend analysis contributes to understanding possible changes rather than constants.

\section{Scenarios and Vignettes}

Scenarios or scenario planning are used frequently in future studies - in the public and private sector (Robertson \& Yeoman, 2014). Shell Oil, for example, has used scenarios to aid its strategic development and capacity since the 1970s (www. shell.com/scenarios). By analyzing underlying social, economic, and political conditions and utilizing a "what if . . . was to happen view" a company (or music festival) may be able to identify, evaluate, and consider emergent trends and uncertainties (Varum \& Melo, 2010; Yeoman, 2008; Yeoman \& McMahon-Beattie, 2005; Yeoman et al., 2012). Constructing scenarios can be used to overcome possible slips in the decision-making process, as well as overconfidence or tunnel vision, which may occur when faced with considering the future

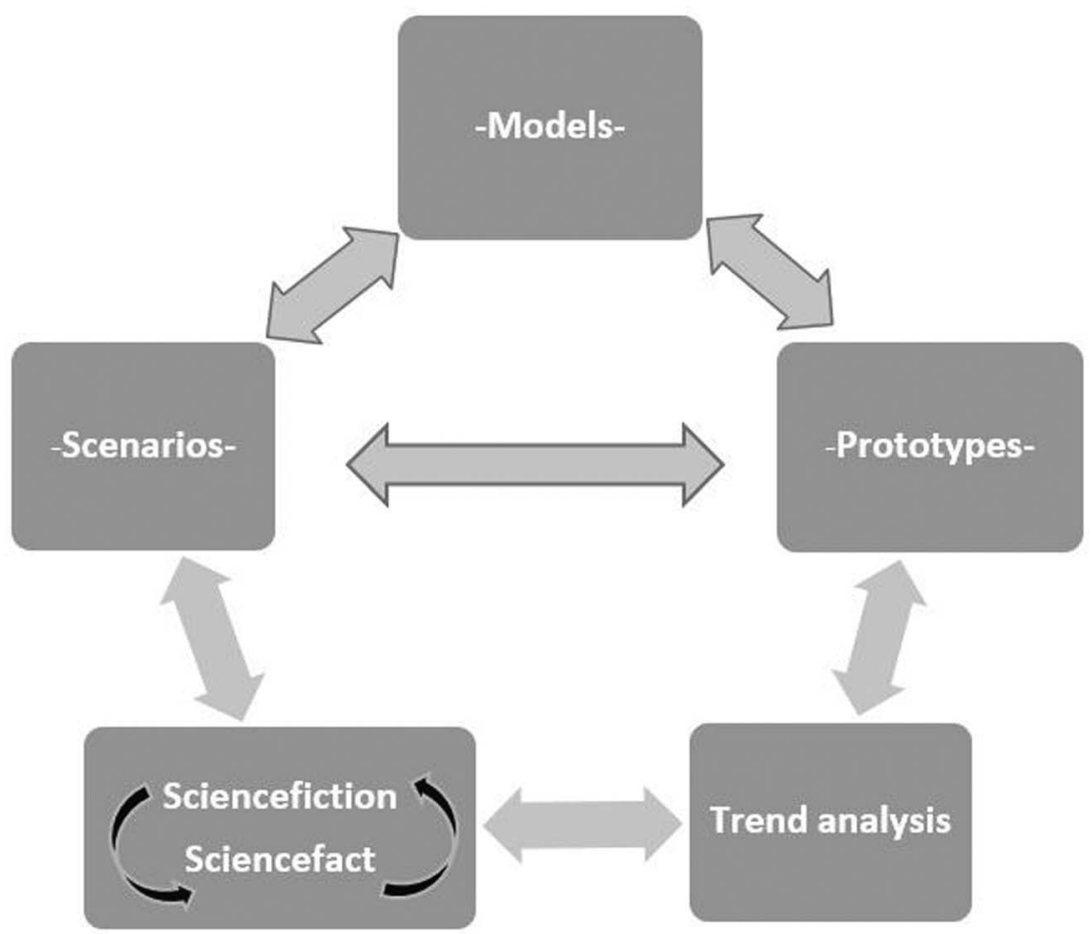

Figure 2. Relationship between forms of management model and scenarios, prototypes, trend analysis, and science (fiction and fact). 
(Varum \& Melo, 2010; Varum, Melo, Alvarenga, \& de Carvalho, 2011).

By bringing together a diverse range of stakeholders and acknowledging the complexity of their multiple perspectives, scenario planning enables a broader perspective of thought. However, the method has been criticized for biased willfulness (i.e., being directed by specific interests if not correctly managed). Lindgren and Bandhold (2003) counter this with a number of rationales for the success of the scenario-planning method. Firstly, they suggest that by reducing complexity to a finite number of divergent options, scenario planning provides a complexity-reducing framework. Secondly, by providing a structure for thinking outside of known parameters, the scenario framework offers a means to communicate more efficiently. Thirdly, the human brain relates easily to stories and the narrative thinking as utilized in scenario thinking. Finally, by forcing the mind to think in qualitatively different directions, the brain can be trained to think the unthinkable (Robertson \& Yeoman, 2014).

One way of facilitating and ensuring clarity of stories is in the use of vignettes. Vignettes are used as distillations of scenarios, offered in the form of a short story to illustrate points of focus and discussion (Eden \& Ackermann, 1998; Rhisiart, 2013; Yeoman, 2012a, 2012b). Vignettes serve to create fictional prototypes (Bell et al., 2013; Birtchnell \& Urry, 2013; Graham et al., 2013; Rhisiart, 2013) and have value as powerful visionary and explanatory tools (Birtchnell \& Urry, 2013; Rhisiart, 2013). They also help to critically observe the information brought forward (Southern et al., 2014). They are used to elucidate and make understandable the process utilized in this work (see Fig. 2).

\section{Analysis}

The visionary analysis is split in two sections. The first section looks at the present in the form of trends, the second section looks at the future, utilizing scenario planning and vignettes.

\section{The Present: Trends}

Yeoman (2013) identified ten consumer trends shaping future events and festivals (Getz \& Page, 2015). These trends are: everyday exceptional; magic nostalgia; leisure upgrade; mobile living; performative leisure; authentic experience; affluence; ageless society; consuming with ethics; and accumulation of social capital. These trends are not repeated in this work, but reference is made to them in the scenarios, in the discussion, and in the concluding section.

The trends discussed are split in two sections. The first (shorter section) introduces two macro trends - urbanization and forms of living and learning. The second (longer section) looks at consumer trends, which are shaping future festivals.

\section{Urbanization}

Urban centers already account for over $50 \%$ of world population (Intergovernmental Panel on Climate Change [IPCC], 2014). Projections indicate that the world's urban population is expected to increase by $72 \%$ by 2050 (from 3.6 billion in the year 2011 to 6.3 billion in the year 2050). The proportion of the world that will have 10 million or more citizens will increase dramatically (United Nations Department of Economic and Social Affairs, Population Division, 2012) and in many cities the process of suburbanization is in reverse with a move towards more dense city centers, encouraging new forms of leisure and work (Moir, Moonen, \& Clark, 2014). Festivals are a part of this growing urban system and an increasingly significant part of the cultural proposition that cities can offer in response to its inhabitants and visitors desire for experience (Pratt, 2014).

\section{Living and Learning Longer}

Trend analysis by Yeoman (2013) indicates that people around the world feel themselves becoming elderly far later in life than ever before. In Germany, France, the Nordic countries, and the UK, 34-45\% of those in the age cohort 70-75 years of age do not perceive themselves as being elderly. People are living more actively for longer and one trend that supports this prolonging of an active lifestyle has been increasing participation in tertiary education and the phenomena of later entrance to tertiary education (Future Foundation, 2015e).

Younger people also perceive that ongoing participation in training and education is important. 
Indeed, they are concerned that they may not be able to get a job without continuing professional development (Future Foundation, 2015b). In a more volatile working environment, with shorter contracts and fewer positions offering on-going permanent employment, and where there is greater access to sources of knowledge, young people are reskilling on an ongoing basis. As signpost of that trend, a worldwide analysis of social media posts (2,855,842 posts-95\% twitter, 5\% Facebook) over a 31-month period recorded the number of instances of the following keywords being used: learning/ learn/ learned; new skills/new things; addicted to learning/love learning. Although there were fluctuations through the years of study, there was a substantial increase year on year, recording 4,015 usages on February 13, 2011, and 56,986 usages on February 15, 2015 (Future Foundation 2015b).

A signal of this growth is the emergence of companies offering services, workshops, and courses that provide short or one-to-one courses or training. An example is MassMutual, a US life-assurance company whose subsidiary organization, Society of Grownups (www.societyofgrownups.com), has responded to what it perceives as a trend towards millennials feeling unprepared as they enter into a life after formal education. The company offers a number of short courses and events that are "designed to help you find out who you are, sort out what you really want, and reach your goalspersonal, professional, or financial” (www.society ofgrownups.com).

Moreover, it is not only during work time that people are seeking new skills. People are also seeking to derive new purpose from their nonwork activities. One other strong signal of a linkage between desire to learn and leisure experience comes from the international analysis by Future Foundation (2015a), which documents that an average of $45 \%$ of respondents saw learning a new skill or activity from entertainment as either valuable or very valuable.

\section{Desire for Personal Control}

A wide-reaching consumer trend is that people want to be in control of their environment at all times. nVision's figures from Europe suggest that up to $72 \%$ of the population wish to appear in control of their life at all times (Future Foundation, 2015c). This may be a response to the feeling of having to multitask in life (e.g., in career, in parenting, in creating and monitoring lifestyle and health) and may also be the consequence of a perceived need to communicate and manage a successful, effective, and visible social media presence at all times (Yeoman, 2013).

As the variety of both experiential and traditional service products expand, and social media perpetuates choice, so too a desire for clarity arises. By utilizing a number of online and social media, people look for curated online content as part of their own curation of online media (Duh et al., 2012; Lui, 2015; Proctor, 2010). Accordingly, information sources such as TripAdvisor-which appear to integrate expert opinion with user input-are more influential than reference sources that do not include collaborative advice. There is evidence that in the UK (in 2014), nearly a third of the population were influenced by online experts (Future Foundation, 2015d).

\section{Convergence and Depth of Experience(s)}

The desire for immersive, engaging, and personalized experience will become more prevalent as technology facilitates it. The integration of usergenerated content (UGC) through an increasing array of third party hardware and online platforms with official material is a recognized trend. The British Broadcasting Company (BBC) used new media technology to give viewers and attendees of both the 2014 Commonwealth Games and Glastonbury Festival (2014) a new interactive and immersive experience. Venue Explorer (www.bbc.co.uk/rd/projects/ venue-explorer) enables viewers to zoom in from a complete view of a stadium to a particular area. Their Augmented Video Player (developed in 2012 to enhance sport-event coverage) allows the layering of additional content (e.g., from different video feeds, social media, and official broadcasts) and is a response by the $\mathrm{BBC}$ to meet the changing immersive needs of its audiences (Velt et al., 2015).

Further, in their exploratory analysis of a sample of television and online viewers of Glastonbury Festival by Velt et al. (2015), respondents indicated a desire to undertake "covert reporting" in which they could capture the perspectives of other festivals attendees; of being able to interview band members on stage and behind the scenes; and of being able to 
craft a festival theme around their mobile devices (i.e., bringing together text and various visual technologies in real time and as a multimedia diary). More recently, the Adelaide Symphony Orchestra in Australia partnered with the company Jumpgate Virtual Reality to offer virtual-reality experiences for audience members. By wearing headsets, the audience was able to mingle with musicians on stage, as well as stand next to the conductor (Keen, 2015). Already now, virtual reality allows activity previously unattainable. In part this is because the realism of the virtual environment is not as important as the social performance the platform can offer. As Grinberg, Careaga, Mehl, and O’Connor's (2014) exploratory behavioral analysis of 35 participants in a virtual hotel showed (using the well-known virtual platform Second Life), social engagement experience is more significant to the participants' sense of immersion than is their spatial (physical) engagement.

\section{Performative, Immediate, and Cocreative Leisure}

The capabilities of mobile devices are transforming the way in which consumers access the Internet. The boundaries of interaction are also becoming increasingly blurred (Velt et al., 2015; Yeoman, 2013) with traditional conceptualizations of the relationships between communication technology and the body (Campbell \& Park, 2008; Hampton, Sessions, \& Her, 2011; Oksman \& Rautininen, 2003; Walsh, White, Cox, \& Young, 2010) becoming more fuzzy.

For an increasing percentage of the population, smart-mobile technology and social networking have aided and pushed real-time narratives (photographic, text, voice, and video) online. It is easier than ever before for consumers to share, and to review activities and experiences, and influence (or be influenced by) peers through multiple mobile choice options (Good, 2012; van Cleemput, 2012). Leisure consumption is becoming synchronous to its broadcast (and discussion). Moreover, status and sense of self for many are wrapped up in these broadcasts, whether they are tweets, Facebook posts (Axelsson, 2010; Hollenbeck \& Kaikati, 2012), or visual stories - using social media platforms such as Storify (https://storify.com), Slideshare (www.slide share.net), or real-time streamed video broadcasts and international discussions using applications such as Periscope (www.periscope.tv) or Meerkat (https://meerkatapp.co ). This is evidence of performative leisure (Future Foundation, 2013; Hannam, 2004), where the consumer is increasingly willing to use leisure moments as real-time records of achievement. Concomitantly, it is also further evidence of a consumer time sensitivity.

The trend of time sensitivity has long permeated the consumer mindset, encouraging us to eliminate "dead" time and use all moments of the day for constructive or rewarding activity (Yeoman, 2008). The result is an ever-growing desire for greater efficiency and convenience in what consumer's do-something that has been coined the culture of immediacy (Kleijnen, Ruytor, \& Wetzels, 2007). In turn, immediacy of service delivery has become a rooted expectation among consumers (Farquhar \& Rowley, 2009).

This desire to ensure that all time is active has, at face value, and controversially, harvested an increasing number of downloadable game applications (apps) (Future Foundation, 2015a). Further, it would appear that games are being used to avoid what may be perceived as spare moments or boring activities (Bailey, Pritchard, \& Kernohan, 2015). Games are also used in social situations (face to face or online), and the concept of gamification has arisen to describe the utility of game design in contexts outside of games (Xu, Weber, \& Buhalis, 2013). Gamification has become strongly associated with marketing, particularly mobile marketing (Bolan, 2015; Zichermann \& Cunningham, 2011), and is considered significant in eliciting motivation and behavioral change in tourism (Xu et al., 2013) and enhancing participation in corporate events (McLoughlin, 2015).

\section{Accordingly, in Looking at Present Trends}

Accordingly, in looking at present trends, the consumer is predominantly urban and involved in leisure for a greater number of years than ever before. Smartphones host more activity, with more advanced and sophisticated functions and games. They improve the user's playing experience and also play a part in people's sense of learning, improvement, and preparation for play and nonplay living. They can also be used to record and broadcast live 
achievement. Play is difficult to define and increasingly difficult to separate from the everyday behaviors of life (Turner, 1969).

Play is liminal, where liminality is the threshold between reality and the unreal. The anthropologist Victor Turner (1969) defined liminality further as being an ambiguous state of being; a transition, a period, or a space "betwixt and between" normal states or conditions - and this is present in many rituals, both sacred and secular. From a tourism perspective, liminal spaces are well documented in the literature (Andrews \& Roberts, 2012), with technology acting as the bridge between reality and (science) fiction.

The Future: How Technology Could Shape Play and Enhance Festival Experience

The previous section identified the relationship between play and technology as a pattern of consumer behavior and provided an evidence base to determine how the present will shape the future.

The next section explores the future, making explanatory claims about future technologies that may seem to be in the realms of science fiction but which can be contextualized by the definition and purpose of Bergman, Karlsson, and Axelsson (2010). A scenario is presented below capturing eleven quantum leap technologies, which further integrates the technology/play paradigm. The scenario has been distilled into a vignette; the short story of Bridgette Wilson at Glastonbury Music Festival in 2030. Eleven technologies that have informed the vignette are addressed here.

\section{Scenario: Glastonbury 2030}

Glastonbury is the World's most popular and high profile music festival. A place to see Elton John Jnr, the Top Cats, XX Top, and Zion Hell play. This is the diary of Bridgette Wilson, a twentyfive-year-old Londoner who has just completed an M.Sc. in Nanotechnology Textile Design. Bridgette has a passion for technology, has all the latest gadgets, and is particularity proud of a new interactive iLens IX that, with a twitch or a blink of an eye, can access the virtual world. Glastonbury is "the" festival to be at and Bridgette and her friends have their tickets for Glastonbury 2030. Bridgette also has a passion for music of all types, whether it be pop, glamour or zing tang.

Over 200 artists are playing at Glastonbury including some new haptic 3D and avatar versions. In Pyramid 22, Elton John Jr. is performing a rendition of Rocket Man while Bridgette's digital tattoo replays the original from 1972. This leads Bridgette to think about rockets, NASA, the moon, allowing her to enter a dream of floating in outer space all to the background of Elton John Jr.'s music. Her dream management recording system captures all of her thoughts and she shares her own rendition with friends and family via her semantic sphere. Moving to Pyramid 32, Hunky Mike is in full flow. Crikey, Bridgette really feels sexy, her clothes have created a sexual arousal in response to the performer's six pack and sensational music. In Pyramid 33 Bridgette can feel the vibrations of zing music through her bracelet indicator. This music is heavy, fast and loud-a head banger special. She decides she needs a beer and purchases a couple of London Prides using her contact lens retinal recognition system. In Pyramid 43 the Avatar Xeatles are playing a range of classic hits-she quickly gets into the groove with a sense of flowers, the 1960s and Abbey Road. The music even gets mixed with Elvis Priestly, Pixie Dott and Tinchy Wink. Bridgette is now creating her own music, mixing it up with friends and artists. "Who's this?" she says, bumping into Maxine Wong on the dance floor. Quickly, using her facial recognition system, she finds out everything about Maxine from the semantic sphere. "Hi Maxine, how's Rosie the cat these days" Bridgette enquires. What a concert, she's been bopping all day long and captured all the concert for remixing later. Can't wait till next year, she thinks, all my friends will be so envious.

\section{Technology One: Cerebral Networks}

Advances in nanotechnologies will allow the transmission of information to others. Bridgette can see, hear, smell, and feel the experience as she immerses herself into the festival experience. How does this work?

Artificial neurons resembling biological neurons are being developed through advances in nanotechnology. As part of parallel computation technology, these artificial neurons can connect to several biological ones. Cerebral networks are therefore a composition 
of interconnecting artificial neurons (programming constructs that mimic the properties of biological neurons). Through reversal deactivation techniques the cerebral network is dynamic, contributing to several (positive) behavior attributes and competencies. Its plasticity tends to minimize induced deficits and contributes to network operations through feed-forward and lateral connections (Arbib, 1995).

There is another advancement that influences the experience dynamic and this is a combination of DNA manipulation, therapy, tissue generation, and robotics (Gullans \& Enriquez, 2011). Named Homo evolutis by Gullans and Enriquez, this development in evolution results in the formation of hominids. Hominids take direct and deliberate control over the evolution of their own species and others. In this environment music festival goers may work with engineers to ensure the best experience is facilitated by a fusion of tissue enhancement and robotic programming.

\section{Technology Two: Digital Tattoos}

Although cerebral networks record experiences, new systems will allow people to play back and enjoy those experiences. Music festival goers may have digital tattoos that use a platform implanted under the skin (Mieke, 2008; Sad, 2012), tapping into the bloodstream and converting oxygen and glucose into electric power. The display functions by changing the color of smart-ink pixels tattooed over the implant (http://www.tomorrowstourist. com/viewpoint.php), allowing tattoos to act as touch screen input devices. It will be possible to manage cell phone calls or access the Internet by tapping on the arm, using the tattoo as a control and communication device.

\section{Technology Three: Emotional Capture}

Although brain implants and digital tattoos may appeal to some, others might prefer classic digital devices. For example, the Philips Rationalizer (Phillips, 2013) concept is an emotional mirror that reflects a person's emotional levels. It uses an onwrist monitor and a small display that alerts the user when emotions are raised as this data is transformed into a pattern through color intensity that is reflected by the monitor.
Technology Four: Feel the Beat in Your Pants

Already seen in gloves that allow gesture-based computing (Ganapati, 2010), in the future, materials used for clothing will have microprocessors and LEDs embedded to create smart textiles. Clothes made entirely of circuit boards could be used to generate music, also to record heartbeats, and perhaps remix these sounds into music. As the scenario indicates, smart textiles will be able to sense the environment, as well as sensing stimuli from that environment, react to them, and adapt to circumstances. Accordingly, clothing will be considered as a second skin and will be brought into an individual's intimate space. In order to enable these smart textiles, a sensor and an actuator are required. A processing unit will drive the actuator on the basis of signals from the sensor. Thus, an intelligent garment will have five functions: sensors, data processors, actuators, information storage, and communication (Mistry \& Maes, 2009).

\section{Technology Five: Semantic Web}

The Semantic Web is the very near future generation of World Wide Web (WWW) technology, enabling machines to understand the meaning of information on the WWW (Hendler \& Berners-Lee, 2010). The search engine, like the brain, must be able to understand texts and queries in the most intuitive way and should be able to communicate information or data back to the user. Powerset, Hakia, and now Google are the major companies currently involved in this new technology. Google's conversational search, using the hummingbird algorithm, is already available (Sullivan, 2013), allowing voice activated searching and a responsive development of that search. The Semantic web means that rather than having one authorized broadcast of a festival, there will thousands of microbroadcasts, all tagged with semantic information based on facts and emotions (Lopez, Fernandez, Motta, \& Stieler, 2012) contributed by individual festival goers.

\section{Technology Six: Curated Content}

Digital curation, as lead by information professionals (Elizabeth, 2007), has been slow to develop (P. Williams, John, \& Rowland, 2009), but with 
technological advances and the capacity to accumulate information, any piece of online digital content or social media feed will soon be collectively curated. An alternative to content generation, content curation amasses content from a variety of sources and delivers it in an organized fashion (Garthwaite, Clausen, Hovey, \& Ownes, 2012). Similarly, festival goers will be able to mix and remix their own versions of a festival, create films, audio soundscapes, or sensory maps as each person will become their own editor (Arcand, 2011).

\section{Technology Seven: Virtual Experiences}

Although at present the experience economy is part of a megatrend (Lorentzen, 2009; Mehmetoglu \& Engen, 2011), future technology will bring about a virtual experience trend. Already, holograms are a reality and appear in festival experiences (Harris, 2013). A hologram being a 3D photograph made with the aid of a laser, which can serve multiple functions (e.g., as a combined lens, aspheric corrector, beam combiner, and narrow filter) (Taylor, 2013). The notion that live performance "takes place at specific time and location and can be listened to only once" (Paleo \& Wijnberg, 2006, p. 50) will be challenged as technology allows live moments to be recorded and/or played elsewhere. While there are queries as to whether or not having 3D holographic television sets for day-to-day viewing adds value, their benefit for live broadcasts and significant events is being discussed more positively (Johnston, 2013).

In its bid to host the 2022 World Cup, Japan proposed beaming matches directly on to pitches in stadiums throughout the world. This was to be made possible by placing 200 8K Ultra-HD TV cameras around the stadium. This 360-degree coverage would record live matches and provide images to be shown on massive flatbed screens laid on the pitch of 400 stadiums across 208 countries (Tanimoto, 2012). If this type of technology were applied to festivals, auto stereoscopic and volumetric displays could be used to provide three dimensional images without requiring the audience to wear specialist equipment.

Currently, auto stereoscopic and volumetric displays are not suitable for large screen theaters and the expense not justifiable for small audience numbers (Yi-Pai, Chen, \& Yi-Chang, 2012). However, these concerns will become a thing of the past if 3D television becomes part of the home infrastructure. As holograms are essentially a thin film and not sensitive to the shape of the substrate to which it is attached, a full-wall television screen becomes a practical proposition. The key to this type of innovation is a photorefractive polymer, a plastic material that allows 3D images to be recorded and updated every 2 seconds (Blanche et al., 2010).

\section{Technology Eight: Dream Management}

By 2050, festival goers will be able to overplay their dreams through a contact lens (as Bridgette does in the scenario) in order to imagine and enhance experiences along with image recognition and emotion detection. Already, research into recording dreams and memories is being carried out at the University of California, using a magnetic resonance imaging scanner while analyzing the flow of blood through the visual cortex (Nishimoto et al., 2011). In this scenario, dreams will be recorded and may be downloaded for future use. Festival goers will be able to relocate the Glastonbury experience to Bali, Las Vegas, or even create their own festival space anywhere they might desire.

\section{Technology Nine: Mind Control}

In the scenario above, Bridgette orders drinks via the festival's mind-reading ordering and delivery bar service. Even using current technology, consumers can use both the power of their mind and physical gestures to play video games. The $3 D$ Vision Gesture Control System (www.gesturetek. com) is a highly precise user interface for interacting with any display screen from any distance, allowing hand motions to control functions in the same way that a keyboard and mouse do at present. This technology allows people to transfer their abilities to a 3D avatar while interacting in real time with computer-generated characters and objects. At the moment, this technology is being experienced in the gaming world (e.g., Nintendo and X-Box 360 game applications) (Hallaian, Lau, Redlawsk, \& Franke, 2012) and is emerging in other fields (Erp, Lotte, \& Tangermann, 2012). Mind control or Brain-Computer Interfacing (Erp et al., 2012) was 
recently demonstrated by Samsung using Electroencephalography (EEG) technology via a Galaxy tablet, as part of a research program to help people with mobility impairments connect with the world (Young, 2013). As a consequence, future festival goers may be able to interact and direct their personalized festival experiences more easily than ever before.

\section{Technology Ten: Haptic Application}

Haptic application involves applying the sense of touch in human-computer interaction and is used to cover a variety of distinct subtypes, including proprioceptive (general sensory information about the body), vestibular (the perception of head motion), kinesthetic (the feeling of motion in the body), and cutaneous (sensory information from the skin). These haptic sensations are created by actuators or motors that create vibrations managed and controlled by embedded software, and integrated into device user interface and application via controlled software (Saddick, Orozco, Eid, \& Cha, 2011). By interacting with human senses this can add a sense of realism to the user experience, giving the sensation of being involved in the action. Applied to music festivals, haptic technologies would allow tactile feedback by applying forces and vibrations, literally allowing participants to feel the music.

\section{Technology Eleven: Contact Lens}

In the scenario, Bridgette uses facial recognition software via contact lens to recognize and search for information about another festival attendee; a function currently available in smartphones. Essentially, display technology used to create visual images occurs when laser light is scanned directly on to the viewer's retina to create a perception of a virtual image. A very small spot is focused onto the retina and is swept over in a raster pattern. These visions might seem farfetched but a contact lens with simple built-in electronics is already within reach at the University of Washingtonthe project is known as "A Twinkle in the Eye" (Parviz, 2009). While we may not currently be using contact lenses in this way, it is the case that Google Glass (www.google.com/glass) delivers many of these features (Olsson, Heinrich, Kelly,
\& Lapetina, 2013; Thad, 2013); looking like a pair of glasses with head mounted display with augmented reality and ubiquitous computing.

\section{Discussion: Can Technology Enhance Music}

Festivals as a Liminal Space in the Future?

As options and opportunities of experience, technical and media choices have gained pace, many music festival experiences have failed to ensure relevance and meaning to the attendee. Although music festivals such as Glastonbury have in times past been able to offer liminal experiences (i.e., an opportunity for joyful play) (Boyce-Tillman, 2009), too often the commonality of music festivalsand their ever increasing number and similarity as leisure experiences-have served to weaken this potential. Engagement with new and virtual landscapes and with the enhanced sensory feelings and imaginations that technologies offer to attendees have delivered new experiences to music festivals. Technology contributes at the interface of music and coshared experience with individual emotional platforms. Importantly, as part of a prototyping process, virtual technology will aid the design of liminal experience at festivals. What is perhaps surprising - in a time of individualism - is that social interaction is very much part of that liminal world, as research on social behavior and traits of those using virtual online environments has indicated (Grinberg et al., 2014; Witmer \& Singer, 1998).

Grinberg et al. (2014) suggest that opportunities for social engagement within the virtual platform Second Life were found to be more significant for the user than were real-life engagements, despite the latter being more realistic (graphically). The conclusion the authors drew from this response was that the social experience had a greater impact on the respondents' sense of immersion than did the spatial experience.

Event managers as experience managers will attempt to record the liminal capacity of event attendees through the very technology that enhances it. The challenge will be in how this wealth of data can be edited, and how to confirm a sustainable form of packaging; replaying and reviewing of the festival experience that continues to resonate with the individual and/or cosharing partners and giving opportunity for immersive social experience. 
Proximity to information and the growth of sophisticated editorial and cross-evaluating technology will allow knowledge to grow exponentially. So while consumers are currently experiencing a period of change that may be identified as a late stage of modernity, consumers are also moving into a more fluid, postmodern existence, making the individual (the "you") part of the cultural growth rather than a consequence of it (Malaska, 2001; Yeoman, 2008). However, the place of the individual will also be aligned to the type or range of technology that is owned — and associated social value that is ascribed to it.

Cultural and social capital is a personal statement as well as a social manifestation. Technology in festivals does have the potential to facilitate liminal space. It may also allow new cultural identities to emerge. It is possible that new patterns and new styles of cultural development will emerge, fed by the sharing of information and the splicing, commenting, and arrangement of image, music, and review.

\section{What Are the Implications of Future Technologies for Music Festivals?}

The value of prototyping and scenario planning has been discussed in this article. The principles of prototyping have been applied in looking at technology, lifestyle, and festivals in the future. The following questions have been asked, in sequence: What is the technology? How will it be used? Who is the consumer? What is the experience? How will the experience be enabled? In addition, a wider vision question has been asked; how will society be improved?

For businesses, the technology-play paradigm is already here. Across all demographic groups, relentless innovation in the gaming-play paradigm means interactive marketing will become more intelligent. It will target specific music festival goers at specific moments, offering incentives, overlaying of experiences, and directing experience possibilities. The importance of understanding self-concept (i.e., the complete ideal one holds of oneself) has already been recognized as being vital to festival management. In the future, this will be far more accountable in driving promotional images and messages used to support, as well as negotiate the self-image desired by, or attractive to, music festival goers (McGuiness \& Overy, 2011). Congruity of self-image with music festival experience will become ever more significant for festival marketers. Similarly, the music festival experience will become more significant for the social experience in an increasingly urbanized future.

As both liminal space and as a place of multiselves (e.g., learner, educated, socially active, performer, and measured), music festivals will have to offer more than a music experience. As the urban environment becomes more significant and the need to ensure multiple activities in a livable city increases, music festivals will coexist with other activities. One example of this is the way in which retail space and festivals will combine (Robertson \& Lees, 2015).

Retail and events can be a response to urbanized society, where the most efficient and socially satisfying use of space is of paramount importance (IPCC, 2014). As both an example of sustainable living and an act of social living, festivals will converge with the built environment more regularly to ensure more efficient use of space. As current visual mapping (projection) is showing, technology can be used very effectively to change the look and sense of place (through smells, lights, utility of worn technology, and sensory tattooing). That is, it can provide platforms for experiences without requiring major structural (building) development. As urbanization develops, it will become increasingly important that open spaces (without buildings) remain in cities to ensure air flow and to offer visual and psychological relief. Therefore, music festivals and retail outlets will often converge to create a cojoined experience in which existing space can be utilized.

Urban spatial strategies of the future will allow the interaction of technologies and multivarious strategies (e.g., urban development, cultural development, festival development, tourism segmentation) but will also be pleasing and attractive and music festivals will be part of that activity. Covert reportage and instant broadcasting will encourage and activate more fashion consciousness-festival attendees will want to look good, therefore proximity to retail venues will be normal. As a form of cocreativity, attendees and performers will be both consuming and cocreative actors of experience (i.e., consumactors) (Cachinho, 2014; Robertson \& Lees, 2015). 


\section{Concluding Thoughts}

This conceptual article began by assessing and highlighting the significance of the relationship of music festivals with technology and the experience that this has helped to facilitate. A review of the related literature suggests that the success of music festivals now and into the immediate future will have an asynchronous relationship with their capacity to allow cocreative activityand the offering of added (depth of) value. The festival industry (and the media that relate to it) is responding to this.

The benefit in understanding the possible experiences of music festival goers of the future is threefold. First, it has been identified that in understanding experience, organizers have greater opportunity to ensure the best and most positive experience for the festival visitor and to negate a negative one, and "enhance, psychological and social wellbeing” (Packer \& Ballantyne, 2011, p. 179). Secondly, experience is a core component of a business management process (Hallberg \& Harsløf, 2013; Newbery \& Farnham, 2013), often enabling both added value to the experience (the product). Thirdly, it offers greater efficiencies, for example, greater ease in communication between the consumer (the attendee), the human resources (staff), and revenue streams (Hallberg \& Harsløf, 2013), that is, ensuring management of experience for transaction success (Verhoef et al., 2009). The literature that has sprung from Pine and Gilmore $(1998,2011)$ is extensive, particularly so in respect of the tourism management discipline and cultural studies. Although less developed in the festival and event management research area, coverage has certainly grown. The function of this article was not to discuss the existing literature but, rather, to indicate the importance (in a rapidly changing and competitive field) of looking into the future.

In research we often dismiss science fiction but, as Bergman et al. (2010) conclude, science fiction has a role to play in bringing explanatory claims to the future. So, again, while many see science fiction as irrelevant it can (and should) be seen as element of real cognitive understanding. As has been indicated, science fiction adds both reflective and participatory value to the prototyping process. Convergence of trends and wider changes will influence festival provision. Demand for the individual, personalized experience, the changing capacities of technology, the fluidity of algorithms that integrate with our wants and desires, and the normalization of cocreative activity allows for a very dynamic future. The success of future festivals will inevitably need to ensure correlation with the intellectual or emotional depth of the participant and their type of involvement. It is possible, indeed, that the future may require options for bespoke event experiences that exclude the virtual and in which technology may iteratively diminish or increase in its significance (Robertson \& Brown, 2014).

The contribution of this article lies, firstly, in presenting how consumers behave in a digital world in which play and technology enhance the liminal state. Secondly, the article offers an explanation of how technology could enhance the festival experience through social capital without diluting authenticity. Finally, this work may act as a guide to the future of music festival consumption and be of benefit to those organizations involved in the practice and business of music festival (experience) management. As Mair and Whitford (2013) conclude in their extensive review of current research in the event management area, "There will always be interesting, innovative and diverse studies contributing to the growing body of literature pertaining to events" (p. 16). In attempting to look at what experience may mean to goers of music festivals in the future, we add to this.

\section{References}

Andersson, T. D., Armbrecht, J., \& Lundberg, E. (2012). Estimating use and non-use values of a music festival. Scandinavian Journal of Hospitality and Tourism, 12(3), 215-231.

Andrews, H., \& Roberts, L. (2012). Liminal landscapes. Travel, experience and spaces in-between. London: Routledge.

Arbib, M. A. (1995) The handbook of brain theory and neural networks. Cambridge, MA: MIT Education.

Arcand, K. (2011). Creating public science with the from Earth to the Universal Project. Science Communication, 33(3), 398-407.

Arcodia, C., \& Whitford, M. (2006). Festival attendance and the development of social capital. Journal of Convention \& Event Tourism, 8(2), 1-18.

Axelsson, A. (2010). Perceptual and personal: Swedish young adults and the their use of mobile phones. New Media and Society, 12(1), 35-54. 
Bailey, P., Pritchard, G., \& Kernohan, H. (2015). Gamification in market research. International Journal of Market Research, 57(1), 17-28.

Ballantyne, J., Ballantyne, R., \& Packer, J. (2014). Designing and managing music festival experiences to enhance attendees' psychological and social benefits. Musicae Scientiae, 18(1), 65-83.

Bell, F., Fletcher, G., Greenhill, A., Griffiths, M., \& McLean, R. (2013). Science fiction prototypes: Visionary technology narratives between futures. Futures, 50, 5-14.

Bergman, A., Karlsson, J. C., \& Axelsson, J. (2010). Truth claims and explanatory claims-An ontological typology of futures studies. Futures, 42(8), 857-865.

Bernick, L. N., \& Boo, S. (2013). Festival tourism and the entertainment age: Interdisciplinary thought on an international travel phenomenon. International Journal of Culture, Tourism and Hospitality Research, 7(2), 169-174.

Bille, T. (2012). The Scandinavian approach to the experience economy - does it make sense? International Journal of Cultural Policy, 18(1), 93-110.

Birtchnell, T., \& Urry, J. (2013). 3D, SF and the future. Futures, 50, 25-34.

Blanche, P., Bablumian, A., Voorakaraam, R., Christenson, C., Lemieux, D., Thomas, J., et al. (2010). Future of photorefractive based holographic 3D display. In Proc. SPIE 7619, Practical Holography XXIV: Materials and Applications, 76190L. Retrieved August 10, 2013, from http://proceedings.spiedigitallibrary.org/proceeding. aspx?articleid=1339701

Blomkvist, J., \& Holmlid, S. (2010). Service prototyping according to service design practitioners. In Proceedings of ServDes, Second Nordic Conference on Service Design and Service Innovation, December 1-3, Linköping, Sweden.

Bolan, P. (2015). A perspective on the near future: Mobilizing events and social media. In I. Yeoman, M. Robertson, U. MacMahon-Beattie, E. Backer, \& K. A. Smith (Eds.), The future of events and festivals (pp. 200-208). Oxford: Routledge.

Boswijk, A. (2013). The power of the economy of experiences: New ways of value creation. In J. Sundbo \& F. Sorensen (Eds.), Handbook on the experience economy (pp. 171-177). Cheltenham, UK: Edward Elgar Publishing Ltd.

Bowen, H. E., \& Daniels, M. J. (2005). Does the music matter? Motivations for attending a music festival. Event Management, 9(3), 155-164.

Boyce-Tillman, J. (2009). The transformative qualities of a liminal space created by musicking. Philosophy of Music Education Review, 17(2), 184-202.

Boyce-Tillman, J. (2013). Music \& well-being-Music as integrative experience Journal of Urban Culture Research, 7, 48-71.

Brand, R., \& Rocchi, S. (2011). Rethinking value in a changing landscape: A model for strategic reflection and business transformation. Eindhoven, Netherlands: Philips Design.
Briscoe, G., \& Mulligan, C. (2014). Digital innovation: The hackathon phenomenon (pp. 1-13). London: Creative Works.

Brooks, S., Magnin, A., \& O’Halloran, D. (2009). Rock On! Bringing strategic sustainable development to music festivals. Progress in Industrial Ecology, an International Journal, 6(3), 285-306.

Brown, S., \& Hutton, A. (2013). Developments in the realtime evaluation of audience behaviour at planned events. International Journal of Event and Festival Management, 4(1), 43-55.

Brown, S., \& James, J. (2004). Event design and management: Ritual sacrifice? In I. Yeoman, M. Robertson, J. Ali-Knight, S. Drummond, \& U. McMahon-Beattie (Eds.), Festival and events management-An international arts and culture perspective (pp. 53-64). Oxford: Butterworth-Heinemann.

Cachinho, H. (2014). Consumerscapes and the resilience assessment of urban retail systems. Cities, 36, 131-144.

Campbell, S., \& Park, Y. (2008) Social implications of mobile telephony: The rise of personal communication society. Sociology Compass, 2(2), 371-387.

Dredge, D., \& Whitford, M. (2010). Policy for sustainable and responsible festivals and events: Institutionalisation of a new paradigm - a response. Journal of Policy Research in Tourism, Leisure and Events, 2(1), 1-13.

Duh, K., Hirao, T., Kimura, A., Ishiguro, K., Iwata, T., \& Au Yeung, C. (2012). Creating stories: Social curation of Twitter messages. In International AAAI Conference on Web and Social Media. Retrieved from https:// www.aaai.org/ocs/index.php/ICWSM/ICWSM12/paper/ view/4578/5028

Eden, C., \& Ackermann, F. (1998). Making strategy: The journey of strategic management. London: Sage Publications Limited.

Elizabeth, Y. (2007). Digital curation. OCLC Systems \& Services: International Digital Library Perspectives, 23(4), 335-340.

Erp, J., Lotte, F., \& Tangermann, M. (2012) Brain-computer interfaces: Beyond medical applications. Computer, 45(4), 26-34.

Evans, G. (2009). Creative cities, creative spaces and urban policy. Urban Studies, 46(5-6), 1003-1040.

Falkheimer, J. (2007). Events framed by the mass media: Media coverage and effects of America's Cup Preregatta in Sweden. Event Management, 11(1-2), 81-88.

Farquhar, J., \& Rowley, J. (2009) Convenience: A service perspective. Marketing Theory, 9(4) 425-438.

Ferdinand, N., \& Williams, N. L. (2013). International festivals as experience production systems. Tourism Management, 34, 202-210.

Flinn, J., \& Frew, M. (2014). Glastonbury: Managing the mystification of festivity. Leisure Studies, 33(4), 418-433.

Frey, B. S. (1994). The economics of music festivals. Journal of Cultural Economics, 18(1), 29-39.

Future Foundation. (2013). Performative leisure. Retrieved July 10, 2013, from http://nvision.futurefoundation.net/ 
Future Foundation. (2015a). Game on-EU key trend. Retrieved March 25, 2015, from http://nvision.future foundation.net/

Future Foundation. (2015b). Liquid skills_EU key trend 2015. Retrieved July 22, 2015, from http://nvision. futurefoundation.net/

Future Foundation. (2015c). Cruise control-EU key trend 2015. Retrieved July 22, 2015, from http://nvision. futurefoundation.net/

Future Foundation. (2015d). Peer power-EU key trend 2015. Retrieved March 25, 2015, from http://nvision. futurefoundation.net/

Future Foundation. (2015e). The lifestage delay-EU key trend 2015. Retrieved February 28, 2015, from http:// nvision.futurefoundation.net/

Ganapati, P. (2010). Gesture-based computing uses \$1 lycra gloves. Retrieved August 12, 2013, from http:// www.wired.com/gadgetlab/2010/05/gloves-gesturecomputing/

Garthwaite, F., Clausen, D., Hovey, P., \& Ownes, W. (2012). Digital content curation and distribution system and method. United States Patent Application 220120271825. Retrieved August 10, 2013, from http://www.freepatent sonline.com/y2012/0271825.html

Gelder, G., \& Robinson, P. (2009). A critical comparative study of visitor motivations for attending music festivals: A case study of Glastonbury and V Festival. Event Management, 13(3), 181-196.

Getz, D., \& Page, S. J. (2015). Progress in tourism management: Progress and prospects for event tourism. Tourism Management, 52, 593-631.

Gibson, C. (2007). Music festivals: Transformations in nonmetropolitan places, and in creative work. Media International Australia, 123, 65-81.

Gibson, C., \& Connell, J. (2005). Music and tourism: On the road again: Bristol, UK: Channel View Publications.

Gibson, C., \& Connell, J. (2012). Music festivals and regional development in Australia. Farnham, UK: Ashgate.

Glastonbury. (2011). Ticket info. Glastonbury Festival of Contemporary Performing Arts.

Glenn, J. C. (2009). Introduction to the futures research methods series. The millenium project. In J. C. Glenn \& T. J. Gordon (Eds.), Future research methodology, version 3.0 (pp. 1-107). Washington, CD: The Millenium Project.

Godet, M., \& Roubelat, F. (1996). Creating the future: The use and misuse of scenarios. Long Range Planning, 29(2), 164-171.

Good, K. (2012). From scrapbook to Facebook: A history of personal media assemblage and archives. Communication, 15(4), 557-573.

Grabner-Krauter, S. (2010). Web 2.0 social networks: The role of trust. Journal of Business Ethics, 90(5), 505-522.

Graham, G., Callaghan, V., \& Greenhill, A. (2013). Exploring business visions using creative fictional prototypes. Futures, 50, 11-14.

Grinberg, A. M., Careaga, J. S., Mehl, M. R., \& O’Connor, M.-F. (2014). Social engagement and user immersion in a socially based virtual world. Computers in Human Behavior, 36, 479-486.

Gullans, S., \& Enriquez, J. (2011) Homo evolutis. New York: Ted Books.

Hagen, U. (1991). A challenge for the actor. New York: Scribner's.

Hallaian, S., Lau, S., Redlawsk, K., \& Franke, E. (2012). Mind control toys and methods of interactions therewith. US Patent No 8157609 B2. Retrieved August 5, 2013, from http://www.patentlens.net/patentlens/patents.html? patnums=US_8157609\&language $=$ \&patnum=US_8157 $609 \&$ language $=$ en \&query $=\&$ stemming $=\& p i d=p 0$

Hallberg, G. W., \& Harsløf, O. (2013). Experiencing everyday life anew: Applied theatrical and performative strategies. In J. Sundbo \& F. Sorensen (Eds.), Handbook on the experience economy (pp. 447-463). Cheltenham, UK: Edward Elgar Publishing.

Hampton, K., Sessions, L., \& Her, E. (2011) Core network, social isolation and new media. Information, Communication and Society, 14(1), 130-155.

Hannam, K. (2004). Tourism and development II: Marketing destinations, experiences and crises. Progress in Development Studies, 4(3), 256-263.

Harris, M. (2013). The hologram of Tupac at Coachella and Saints: The value of relics for devotees. Celebrity Studies, 4(2), 238-240.

Hauptfleisch, T. (2006). Eventifying identity: Festivals in South Africa and the search for cultural identity (festivals, their audiences and identities, and the plays they attract). New Theatre Quarterly, 22(86), 181-198.

Hendler, J., \& Berners-Lee, T. (2010) From the semantic web to social machines: A research challenge for AI on the World Wide Web. Artifical Intelligence, 174(2), 156-161.

Holbrook, M. B., \& Hirschman, E. C. (1982). The experiential aspects of consumption: Consumer fantasies, feelings, and fun. Journal of Consumer Research, 9(2), 132-140.

Hollands, R. G. (2010). Engaging and alternative cultural tourism? Journal of Cultural Economy, 3(3), 379-394.

Hollenbeck, C. R., \& Kaikati, A. M. (2012). Consumers' use of brands to reflect their actual and ideal selves on Facebook. International Journal of Research in Marketing, 29(4), 395-405.

Howard-Grenville, J., Golden-Biddle, K., Irwin, J., \& Mao, J. (2011). Liminality as cultural process for cultural change. Organization Science, 22(2), 522-539.

Hudson, S., \& Hudson, R. (2013). Engaging with consumers using social media: A case study of music festivals. International Journal of Event and Festival Management, 4(3), 206-223.

Intergovernmental Panel on Climate Change. (2014). Cities as barometer and guardians-Intergovernmental plan on climate change (5th assessment report, November 2014). Retrieved April 24, 2015, from www.ipcc.ch

Johnson, B. D. (2011). Science fiction prototyping: Designing the future with science fiction. Synthesis lecture on Computer Science. San Rafael, CA: Morgan and Claypool Publishers. 
Johnston, K. M. (2013). “Pop-out footballers,” pop concerts and popular films: The past, present and future of threedimensional television. Convergence: The International Journal of Research into New Media Technologies, 19(4), 438-445.

Keen, S. (2015, July 15). ASO offers virtual-reality concert experience. Indaily Adelaide Independent News. Retrieved July 22, 2015, from http://indaily.com.au/artsand-culture/music/2015/07/15/aso-offers-virtual-realityconcert-experience/

Kirby, D. (2010). The future is now: Diegetic prototypes and the role of popular films in generating real-world technological development. Social Studies of Science, 40(1), 41-70.

Kleijnen, M., Ruytor, K., \& Wetzels, M. (2007). An assessment of value creation in mobile service delivery and the moderating role of time consciousness. Journal of Retailing, 83(1), 33-46.

Laing, J., \& Mair, J. (2015). Music festivals and social inclusion-The festival organizers' perspective. Leisure Sciences, 37(3), 1-17.

Langer, S. K. (1953). Feeling and form: A theory of art. New York : Charles Scribner's Sons.

Lee, I. S., Charles, A., \& Lee, T. J. (2012). Multicultural festivals: A niche tourism product in South Korea. Tourism Review, 67(1), 34-41.

Lindgren, M., \& Bandhold, H. (2003). Scenario planning: The link between future and strategy. New York: Palgrave Macmillan.

Lockstone, L., \& Smith, K. A. (2009). Involving and keeping event volunteers: Management insights from cultural festivals. In T. Baum, M. Deery, C. Hanlon, L. Lockstone, \& K. A. Smith (Eds.), People and work in events and conventions: A research perspective (pp. 154-168). Wallingford, UK: CABI.

Lopez, V., Fernandez, M., Motta, E., \& Stieler, N. (2012). PowerAqua: Supporting users in querying and exploring the semantic web. Semantic Web, 3(3), 249-265.

Lorentzen, A. (2009). Cities in the experience economy. European Planning Studies, 17(6), 829-845.

Lui, D. (2015). Public curation and private collection: The production of knowledge on Pinterest.com. Critical Studies in Media Communication, 32(2), 128-142.

Luxford, A., \& Dickinson, J. E. (2015). The role of mobile applications in the consumer experience at music festivals. Event Management, 19(1), 33-46.

Mair, J. (2014). Events as proenvironmental learning spaces. Event Management, 18(4), 421-429.

Mair, J., \& Whitford, M. (2013). An exploration of events research: Event topics, themes and emerging trends. International Journal of Event and Festival Management, 4(1), 6-30.

Malaska, P. (2001) A futures research outline of a post-modern idea of progress. Futures, 33(3-4), 225-243.

Mayfield, T. L., \& Crompton, J. L. (1995). Development of an instrument for identifying community reasons for staging a festival. Journal of Travel Research, 33(3), 37-44.
McCarthy, B. (2013). The landscape of music festivals in Australia. In P. Tschmuck, P. L. Pearce, \& S. Campbell (Eds.), Music business and the experience economy. The Australasian case (pp. 119-134). Heidelberg, New York, Dordrecht, \& London: Springer.

McGuiness, A., \& Overy, K. (2011) Music, consciousness, and the brain: Music as shared experience of an embodied present. In D. Clark \& E. Clark (Eds.), Music and consciousness: Philosophical, psychological, and cultural perspectives (pp. 245-261). Oxford: Oxford University Press.

McLoughlin, A. (2015). The future of event design and experience. In I. Yeoman, M. Robertson, U. McMahon-Beattie, E. Backer, \& K. A. Smith (Eds.), The future of events and festivals (pp. 236-250). Oxon, UK: Routledge.

Mehmetoglu, M., \& Engen, M. (2011). Pine and Gilmore’s concept of experience economy and its dimensions: An empirical examination in tourism. Journal of Quality Assurance in Hospitality \& Tourism, 12(4), 237-255.

Mieke, J. (2008). Digital tattoo's interface. Retrieved from http://phys.org/news/2008-02-electronic-tattoo-blood. html

Miettinen, S., Valtonen, A., \& Markuksela, V. (2015). Service design methods in event design. In G. Richards, L. Marques, \& K. Mein (Eds.), Event design: Social perspectives and practices (pp. 25-35). Oxon, UK: Routledge.

Mistry, P., \& Maes, P. (2009). SixthSense-A wearable gestural interface. In the Proceeding of SIGGRAPH Asia. Emerging Technologies, Yokohama. Retrieved August 10, 2013, from http://dl.acm.org/citation.cfm?id=1667160

Moir, E., Moonen, T., \& Clark, G. (2014). The future of cities: What is the global agenda? (UK Foresight Future of Cities Project Government Office for Science). Retrieved from https://www.gov.uk/government/uploads/system/uploads/ attachment_data/file/429125/future-cities-global-agenda. pdf

Moital, I., Jackson, C., \& Le Couillard, J. (2013). Using scenarios to investigate stakeholders' views on the future of a sporting event. Event Management, 17(4), 439-452.

Nelson, K. B. (2009). Enhancing the attendee's experience through creative design of the event environment: Applying Goffman's dramaturgical perspective. Journal of Convention \& Event Tourism, 10(2), 120-133.

Newbery, P., \& Farnham, K. (2013). Experience design: A framework for integrating brand, experience, and value. Hoboken, NJ: Wiley.

Nishimoto, S., Vu, A. T., Naselaris, T., Benjamini, Y., Yu, B., \& Gallant, J. L. (2011). Reconstructing visual experiences from brain activity evoked by natural movies. Current Biology, 21(19), 1641-1646.

Nordvall, A., Pettersson, R., Svensson, B., \& Brown, S. (2014). Designing events for social interaction. Event Management, 18(2), 127-140.

Oksman, V., \& Rautininen, P. (2003) Extension of the hand: Children's and teenagers relationship with the mobile phone in Finland. In L. Fortuntati, J. Katz, \& R. Riccini (Eds.), Mediating the human body: Technology, сотmunications and fashion (pp 103-111). Mahwah, NJ: Lawrence Earlbaum Associates. 
Olsson, M., Heinrich, M., Kelly, D., \& Lapetina, J. (2013) Wearable device with input and output structures. US Patent and Trademark Office. Retrieved August 31, 2013, from http://appft.uspto.gov/netacgi/nph-Parse r?Sect $1=$ PTO2\&Sect2=HITOFF \&u=\%2Fnetahtml\% 2FPTO\%2Fsearch-adv.html\&r=13\&p=1\&f=G\&l=5 0\&d=PG01\&S1=\%2820130221.PD.\%20AND\%20 Google.AS.\%29\&OS=PD/20130221\%20AND\%20AN/ Google\&RS=\%28PD/20130221\%20AND\%20AN/ Google\%29

Packer, J., \& Ballantyne, J. (2011). The impact of music festival attendance on young people's psychological and social well-being. Psychology of Music, 39(2), 164-181.

Paleo, I. O., \& Wijnberg, N. M. (2006). Classification of popular music festivals: A typology of festivals and an inquiry into their role in the construction of music genres. International Journal of Arts Management, 8(2), 50-61.

Parker, M., Fournier, V. R., \& Reedy, P. (2007). The dictionary of alternatives: Utopianism and organization. New York: Zed Books Ltd.

Parviz, B. A. (2009). Augmented reality in a contact lens. IEEE Spectrum. Retrieved August 10, from http://spec trum.ieee.org/biomedical/bionics/augmented-reality-ina-contact-lens

Pegg, S., \& Patterson, I. (2010). Rethinking music festivals as a staged event: Gaining insights from understanding visitor motivations and the experiences they seek. Journal of Convention \& Event Tourism, 11(2), 85-99.

Phillips. (2013). Rationalizer. Retrieved August 13, 2013, from http:/www.design.philips.com/about/design/design portfolio/design_futures/rationalizer.page

Pine, B. J., \& Gilmore, J. H. (1998). Welcome to the experience economy. Harvard Business Review, 76, 97-105.

Pine, B. J., \& Gilmore, J. H. (2011). The experience economy (updated version). Boston, MA: Harvard Business Review Press.

Pratt, A. C. (2014). Future of cities: The cultural dimension. (GS/14/821). London Foresight, Government office for science. Retrieved from www.gov.uk/government/ publications/future-of-cities-the-cultural-dimension

Proctor, N. (2010). Digital: Museum as platform, curator as champion, in the age of social media. Curator: The Museum Journal, 53(1), 35-43.

Putnam, H. (1981). Reason, truth and history. Cambridge, MA: Cambridge University Press.

Ramaswamy, V., \& Gouillart, F. (2010). Building the co-creative enterprise. Harvard Business Review, 88(10), 100-109.

Rhisiart, M. (2013). Exploring the future for arts and culture organisations through scenarios and vignettes. Futures, 50, 15-24.

Rihova, I., Buhalis, D., Moital, M., \& Gouthro, M.-B. (2014). Conceptualising customer-to-customer value co-creation in tourism. International Journal of Tourism Research, 7(4), 356-363.

Robertson, M., \& Brown, S. (2014). Leadership and visionary futures: Future proofing festivals. In I. Yeoman, M. Robertson, U. McMahon-Beattie, K. A. Smith, \& E.
Backer (Eds.), The future of events and festivals (pp. 219-235). Oxon, UK: Routledge.

Robertson, M., \& Lees, G. (2015). Escaping the city, retailvents in socio-spatially managed futures. In I. Yeoman, M. Robertson, U. McMahon-Beattie, K. A. Smith, \& E. Backer (Eds.), The future of events and festivals (pp. 251-267). Oxon, UK: Routledge.

Robertson, M., \& Rogers, P. (2009). Festivals, cooperative stakeholders and the role of the media: A case analysis of newspaper media. Scandinavian Journal of Hospitality and Tourism, 9(2), 206-224.

Robertson, M., \& Yeoman, I. (2014). Signals and signposts of the future: Literary festival consumption in 2050. Tourism Recreation Research, 39(3), 321-342.

Roselyne, N. O. (2011). Promoting sustainable festival events tourism: A case study of Lamu Kenya. Worldwide Hospitality and Tourism Themes, 3(3), 193-202.

Ryan, C. (2012). The experience of events. In S. J. Page \& J. Connell (Eds.), The Routledge handbook of events (pp. 248-259). Oxon, UK: Routledge.

Saco, R. M., \& Goncalves, A. P. (2008). Service design: An appraisal. Design Management Review, 19(1), 10-19.

Sad, B. (2012). O design de interfaces epiteliais dinamicas: Como as novas techologias afetam o projecto de tatuagens. Ph.D. thesis, Universidade do Estado do Rio de Janeiro, Rio de Janeiro, Brazil.

Saddick, A., Orozco, M., Eid, M., \& Cha, J. (2011) Touching the future: HAVE challenges and trends. In A. Saddick, M. Orozco, M. Eid, \& J. Cha (Eds), Haptic technologies: Bringing touch to multimedia (pp. 183-194). Heidelberg, Berlin: Springer.

Sanders, E. B. N., \& Stappers, P. J. (2008). Co-creation and the new landscapes of design. CoDesign, 4(1), 5-18.

Scheufele, D. A., \& Tewksbury, D. (2007). Framing, agenda setting, and priming: The evolution of three media effects models. Journal of Communication, 57(1), 9-20.

Selwood, S. (2007). Future uncertain: Arts council England's vision for the future of the contemporary visual arts. Futures, 39(10), 1201-1222.

Shimrary, S., \& Ramaiah, C.(2015) Design and development of an online exhibition on the Tangkhul Tribe Festivals. DESIDOC Journal of Library \& Information Technology, 35(2). Retrieved June, 28, 2015, from http://publications.drdo.gov.in/ojs/index.php/djlit/arti cle/view/8396

Simo, R., Satu, M., Essi, K., \& Antti, L. (2012). A laboratory concept for service prototyping-Service innovation corner (SINCO). Proceedings of ServDes. Retrieved March 8, 2013, from http://www.servdes.org/pdf/2012/ rontti-miettinen-kuure-lindstrom.pdf

Smith, S. L. (1994). The tourism product. Annals of Tourism Research, 21(3), 582-595.

Southern, J., Ellis, R., Ferrario, M. A., McNally, R., Dillon, R., Simm, W., et al. (2014). Imaginative labour and relationships of care: Co-designing prototypes with vulnerable communities. Technological Forecasting and Social Change, 84, 131-142. 
Stamboulis, Y., \& Skayannis, P. (2003). Innovation strategies and technology for experience-based tourism. Tourism Management, 24(1), 35-43.

Sullivan, D. (2013). FAQ: All about the new Google "hummingbird" algorithm. Retrieved from http://searchengine land.com/google-hummingbird-172816

Tanimoto, M. (2012). FTV: Free-viewpiont television. Signal Processing: Image Commication, 27(6), 555-570.

Taylor, R. (2013). A curious conundrum: The state of holographic portraiture in the 21st century. Journal of Physics: Conference Service, 415(1), 1-15. Retrieved August 21, 2013, from http://iopscience.iop.org/1742-6596/415/1/ 012004/pdf/1742-6596_415_1_012004.pdf

Thad, S. (2013). Project Glass: An extension of the self. Pervasive Computing IEEE, 12(2), 14-16.

Turner, V. W. (1969) The ritual process: Structure and antistructure. Chicago, IL: Aldine.

United Nations Department of Economic and Social Affairs, Population Division. (2012). World urbanization prospects: The 2011 revision (CD Rom edition, POP/DB/ WUP/Rev.2011).

Van Cleemput, K. (2012) Friendship type, clique formation and the everyday use of communication technologies in peer group. Information, Communication and Society, 15(8), 1258-1277.

van der Helm, R. (2009). The vision phenomenon: Towards a theoretical underpinning of visions of the future and the process of envisioning. Futures, 41(2), 96-104.

van Limburg, B. (2008). Innovation in pop festivals by cocreation. Event Management, 12(2), 105-117.

Van Rekom, J. (1995). Adding psychological value to tourism products. Journal of Travel \& Tourism Marketing, 3(3), 21-36.

Varum, C. A., \& Melo, C. (2010). Directions in scenario planning literature-A review of the past decades. Futures, 42(4), 355-369.

Varum, C. A., Melo, C., Alvarenga, A., \& de Carvalho, P. S. (2011). Scenarios and possible futures for hospitality and tourism. Foresight, 13(1), 19-35.

Velt, R., Benford, S., Reeves, S., Evans, M., Glancy, M., \& Stenton, P. (2015). Towards an extended festival viewing experience (pp. 53-62). Proceedings of the ACM International Conference on Interactive Experiences for TV and Online Video, June 3-5, Brussels, Belgium.

Verhoef, P. C., Lemon, K. N., Parasuraman, A., Roggeveen, A., Tsiros, M., \& Schlesinger, L. A. (2009). Customer experience creation: Determinants, dynamics and management strategies. Journal of Retailing, 85(1), 31-41.

Walmsley, B. (2013). Co-creating theatre: Authentic engagement or inter-legitimation? Cultural Trends, 22(2), 108-118.

Walsh, S., White, K., Cox, S., \& Young, R. (2010) Keeping in constant touch: The predictors of young australian mobile phone involvement. Computers in Human Behaviour, 27(3), 333-342.
Whitford, M. (2009). A framework for the development of event public policy: Facilitating regional development. Tourism Management, 30(5), 674-682.

Williams, N. L., Inversini, A., Buhalis, D., \& Ferdinand, N. (2015). Community crosstalk: An exploratory analysis of destination and festival eWOM on Twitter. Journal of Marketing Management, 31(9-10), 1-28.

Williams, P., John, J. L., \& Rowland, I. (2009). The personal curation of digital objects. Aslib Proceedings: New Information Perspectives, 61(4), 340-363.

Witmer, B. G., \& Singer, M. J. (1998). Measuring presence in virtual environments: A presence questionnaire. Presence: Teleoperators and Virtual Environments, $\overline{7(3)}$, 225-240.

Xu, F., Weber, J., \& Buhalis, D. (2013). Gamification in tourism. In Z. Xiang \& I. Tussyadiah (Eds.), Information and communication technologies in tourism 2014 (pp. 525-537): Cham, Switzerland: Springer International Publishing.

Yeoman, I. (2008). Tomorrow's tourist: Scenarios \& trends. Oxford: Butterworth-Heinemann.

Yeoman, I. (2012a). 2050: Tomorrows tourism. Bristol, UK: Channelview.

Yeoman, I. (2012b). Our sustainable future_-Looking back from 2050. In G. Lipman, T. DeLacy, R. Hawkins, S. Vorster, \& M. Jiang (Eds.), Green growth and travelism: Letters from leaders. Oxford: Goodfellows.

Yeoman, I. (2013) A futurists thoughts on consumer trends shaping future festivals and events. International Journal of Event and Festival Management, 4(3), 249-260.

Yeoman, I., \& McMahon-Beattie, U. (2005). Developing a scenario planning process using a blank piece of paper. Tourism and Hospitality Research, 5(3), 273-935.

Yeoman, I., Robertson, M., \& Smith, K. A. (2012). A futurist's view on the future of events. In S. J. Page \& J. Connell (Eds.), The Routledge handbook of events (pp. 507-525). Oxon, UK: Routledge.

Yeoman, I., Robertson, M., \& Wheatley, C. (2015). Cognitive map(s) of event and festival futures. In I. Yeoman, M. Robertson, U. McMahon-Beattie, E. Backer, \& K. A. Smith (Eds.), The future of events and festivals (pp. 271-313). Oxon, UK: Routledge.

Yi-Pai, H., Chen, C., \& Yi-Chang, H. (2012). Superzone fresnel crystal lens for temporal scanning auto-stereoscopic display. Journal of Display Technology, 8(11), 650-655.

Young, S. (2013). Samsung demos a tablet controlled by your brain. MIT Technology Review. Retrieved August 10, 2013, from http://www.technologyreview.com/news/513861/sam sung-demos-a-tablet-controlled-by-your-brain/

Zbikowski, L. M. (2010) Music, emotion, analysis. Music Analysis, 29(1-3), 37-60.

Zichermann, G., \& Cunningham, C. (2011). Gamification by design: Implementing game mechanics in web and mobile apps. Sebastopol, CA: O’Reilly Media, Inc. 